\title{
PENGEMBANGAN BAHAN AJAR ENGLISH-TEXTUAL-GENRE BERBASIS ANDROID DALAM IMPLEMENTASI PPK KURIKULUM 2013 EDISI REVISI
}

\author{
Didit Kurniadi ${ }^{1}$, Mohamad Fajarianditya Nugroho ${ }^{2}$ \\ Program Studi Sastra Inggris, Fakultas Bahasa dan Budaya, Universitas AKI \\ e-mail: didit.light@gmail.com \\ Program Studi Teknik Informatika, Fakultas Teknik Informatika, Universitas AKI \\ e-mail: mohamad.fajarianditya@unaki.ac.id
}

\begin{abstract}
The implementation of the revised edition of the Curriculum of 2013 in Indonesia for millennial generation students does not focus on increasing the competency of the subjects only, but rather on improving the character, especially independence. This research is based on the issue of whether there is a significant relationship between teaching materials based on ETG (Educational Technology Gadget) on improving the competence of students' IBC and English as well as differences in student achievement in English subjects taught on an ETG basis when compared with non-ETG. The objectives to be achieved in this study are to investigate and examine whether there is a significant relationship between ETG-based teaching materials on improving the competence of IBC and English students and to find out whether there are differences in student achievement in English subjects taught with ETG-based if compared to non ETG ones. The research method is $R \& D$ with a type of factorial design research sourced from quantitative experiments. Beyond literature studies, curriculum analysis, and surveys, research starts from pre-test, treatment, post-test, data collection and analysis which are then concluded as indicators of performance.
\end{abstract}

Keywords: Character, Millenial Generation, IBC, English, ETG

\section{PENDAHULUAN}

Bahan ajar bahasa inggris di sekolahsekolah Indonesia masih banyak yang berupa textual-genre. Hal tersebut dituangkan di Silabus yang sudah ditentukan dan dikembangkan bahan ajarnya secara lebih spesifik lagi baik oleh guru mata pelajaran Bahasa Inggris terkait secara individu maupun kelompok dan masih perlu ditingkatkan. Hal tersebut perlu dipertimbangkan mengingat kurikulum di
Indonesia masih terus berubah, seperti contohnya perubahan terakhir dari kurikulum 2013 menjadi kurikulum 2013 edisi revisi. Banyak hal yang berganti dari perubahan tersebut dimana pemerintah pada tngkatan SMP ikut serta difokuskan dalam implementasi penerapan PPK (Penguatan Pendidikan Karakter) di kurikulum 2013 edisi revisi yang meliputi integrasi olah hati (etik), olah rasa (estetis), olah pikir (literasi), dan olahraga (kinestetik) (14). Hal itu berefek pada perubahan besar di kurikulum, silabus, 
rencana pembelajaran, termasuk materi dan bahan ajarnya. Akhirnya, pemerintah mengganti buku yang sudah tersebar dengan buku yang terbaru untuk menyesuaikan perubahan tersebut. Terlebih, di kurikulum teranyar tersebut "mengharuskan" siswa untuk belajar lebih mandiri, tidak cuma bergantung pada guru yang bertugas sebagai fasilitator di kelas dan tetap mempunyai perilaku yang baik sesuai dengan PPK (Penguatan Pendidikan Karakter) dimana kata "mandiri" (independent) adalah salah satu dari integrasi PPK dari lima nilai karakter (religious, nasionalis, integritas, gotong royong, dan mandiri) yang sangat perlu diterapkan.

Derasnya kemajuan teknologi tidak bisa semuanya dibendung dengan hal-hal yang berbau konvensional. Kemajuan tersebut berdampak pada banyak aspek kehidupan termasuk generasi milineal. Generasi milineal zaman sekarang sudah menganggap teknologi sebagai "kebutuhan primer" mereka. Terbukti dengan setiap anak saat ini sudah mempunyai gadget mereka masing-masing di kehidupan mereka. Kebanyakan dari mereka menggunakan gadget yang berbasis android yang mana mereka dapat mencari informasi yang mereka inginkan dengan cepat melebihi informasi yang mereka dapat di sekolah. Mereka bisa dengan mudah dan cepat mendapatkan aplikasi-aplikasi android (apk) yang dapat mecukupi kebutuhan informasi dengan efektif. Sayangnya, dengan kurikulum yang selalu berubah-ubah, belum banyak bahan ajar yang tersedia yang mengerucut pada bahan ajar yang sesuai dengan materi yang seharusnya dipelajari sesuai dengan kurikulum 2013 edisi revisi yang sangat komprehensif untuk segala perilaku siswa baik untuk proses maupun hasil pencapaian yang dapat diukur dari nilai ketuhanan (spiritual), sosial, pengetahuan, dan keterampilan. Jadi, Bahan ajar untuk siswa generasi milenial sudah seharusnya perlu disesuaikan dengan perkembangan teknologi untuk suplemen belajar mereka dan lebih mandiri.

Mempunyai kompetensi pada mata pelajaran Bahasa Inggris saja tidaklah cukup. Pemerintah ingin generasi penerus tidak berfokus pada aspek keilmuan saja, tetapi juga diharapkan mempunyai perilaku yang mulia. Hal ini dapat dilihat dari upaya pemerintah, salah satunya tertuang nilai-nilai perilaku atau sikap yang ada di Kompetensi Inti (KI) maupun Kompetensi Dasar (KD) di kurikulum atau silabus yang sudah ditentukan. Nilai-nilai sikap yang ada misalnya sikap saling menghargai dan menghayati ajaran agama yang dianut, jujur, 
disiplin, tanggung jawab, toleransi, gotong royong, santun, dan percaya diri. Nilai sikap atau perilaku tersebut diharapkan mampu menambahkan nilai-nilai kemandirian dan sikap atau perilaku positif yang tertuang di bahan ajar di teks-teks (based genre) bahasa inggris yang sesuai dengan ekspektasi peneliti melalui independent-behaviourconstruction, yaitu bahan ajar yang mengandung nilai sikap secara mandiri tanpa mengurangi keilmuan bahasa inggris itu sendiri.

\section{TINJAUAN PUSTAKA}

Pengembangan bahan ajar Bahasa inggris memang sudah seharusnya berada di titik teknologi. Oleh karena itu, peniliti berupaya menambahkan pengembangan bahan ajar yang mudah dan praktis sebagai suplemen bahan ajar yang sudah ada, baik yang konvensional maupun modern. Bahan ajar konvensional yaitu buku-buku, baik buku yang sudah dibagikan oleh pemerintah maupun yang dijual oleh penerbit-penerbit swasta. Bahan ajar yang modern mengkaitkan teknologi sebagai pendukung, seperti audio-visual file yang dilampirkan oleh penerbit buku swasta, ataupun dari para pemangku kepentingan itu sendiri, baik lembaga-lembaga pendidikan, guru, dan peneliti di website maupun blog mereka yang sangat mudah diunduh secara gratis maupun berbayar di era digital ini.

Bahan ajar tentu saja menyesuaikan dengan proses pembelajaran Bahasa Inggris di SMP/MTs yang berbasis teks, baik jenis teks (genre), teks fungisonal pendek, serta teks transaksional dan interpersonal. Salah satu yang sangat sesuai dengan penerapan nilai karakter adalah pembelajaran bahasa inggris yang berbasis Genre. Menurut Dirgeyasa (2016), Genre berasal dari bahasa Prancis yang berarti "bentuk" atau "tipe", dimana kata genre tersebut digunakan dalam banyak bidang, salah satunya seperti Biologi (Genus) yang mana istilah tersebut untuk mengklasifikasikan jenis flora maupun fauna. Musik, film, literature juga menggunakan kata Genre untuk mengkategorikan jenisjenis dari bidang tersebut. Penggunakan istilah Genre juga sampai pada ilmu linguistik terapan, yang mana berarti proses atau serangkaian komunikasi baik lisan maupun tulisan yang mana mempunyai tujuan tertentu. Tujuan tersebut mengenai konteks sosial yang biasanya disebut fungsi sosial (social function).

Jenis teks (Genre) sebagai bahan ajar pada SMP / MTs adalah sebagai berikut: 


\begin{tabular}{|l|l|l|}
\hline No & \multicolumn{1}{|c|}{$\begin{array}{c}\text { Jenis Teks } \\
\text { (Genre) }\end{array}$} & \multicolumn{1}{c|}{ Tujuan Komunikatif / Fungsi Sosial } \\
\hline 1 & Descriptive & $\begin{array}{l}\text { Untuk menggambarkan sesuatu kepada pembaca } \\
\text { mengenai orang, benda, atau tempat, sehingga pembaca } \\
\text { seolah-olah bisa membayangkan, melihat, merasakan } \\
\text { objek yang digambarkan }\end{array}$ \\
\hline 2 & Narrative & $\begin{array}{l}\text { Untuk menghibur pembaca dari cerita yang tidak nyata, } \\
\text { seperti cerita rakyat, fable, dongeng, legenda, dan lain- } \\
\text { lain sehingga secara tersirat memberikan nilai moral }\end{array}$ \\
\hline 3 & Procedure & $\begin{array}{l}\text { Untuk menunjukkan bagaimana cara melakukan untuk } \\
\text { membuat sesuatu kepada pembaca dengan serangkaian } \\
\text { langkah-langkah }\end{array}$ \\
\hline 4 & Recount & $\begin{array}{l}\text { Untuk menceritakan kembali serangkaian peristiwa, } \\
\text { kejadian di masa lampau }\end{array}$ \\
\hline 5 & Report & $\begin{array}{l}\text { Untuk memberikan informasi kepada pembaca } \\
\text { mengenai suatu hal sebagai hasil pengamatan yang } \\
\text { sistematis dan analisis }\end{array}$ \\
\hline
\end{tabular}

Tabel 1. Jenis English-Text-Genre

Perkembangan teknologi sekarang telah memberikan pengaruh yang besar pada dunia pendidikan sekarang ini. Terutama dalam membuat media pembelajaran yang bersifat independen dan berbasis teknologi menjadi daya tarik bagi para siswa untuk meningkatkan motivasi belajar dan mendidik siswa untuk dapat belajar secara mandiri. Sekarang pun, pengembangan media pembelajaran sekarang sudah menggunakan android. Beberapa penelitian dan pengembangan media pembelajaran berbasis android telah banyak dilakukan seiring dengan perkembangan teknologi. Beberapa diantaranya, Yogo, dkk. (2015) menggunakan pembelajaran berbasis android pada mata pelajaran kimia pada siswa sekolah guna mengetahui pengaruh pembelajaran berbasis teknologi dalam mata pelajaran kimia terhadap motivasi belajar siswa. Model penelitian menggunakan model post-test, pre-test, dan control group design. Dari hasil eksperimen yang telah dilakukan, 
disimpulkan bahwa penggunaan aplikasi android sebagai media pembelajaran siswa memiliki hasil yang baik pada penerapan mata pelajaran kimia.

Penelitian yang sejenis dilakukan juga oleh Nunung, dkk. (2018) untuk pembelajaran Bahasa Jepang. Guna mempermudah siswa SMK dalam mempelajari bahasa Jepang dengan model yang interaktif dan tidak membuat jenuh dengan metode tradisional, maka dibentuk media pembelajaran interaktif berbasis android dalam bentuk animasi. Dalam pengembangan aplikasi android menggunakan model waterfall, dan dibagi menjadi beberapa menu, diantaranya menu untuk materi huruf katakana dan hiragana, dan latihan soal dari materi yang telah dipelajari.

Musahraim, dkk. (2017) dan Rahmat, dkk. (2018) menerapkan pembelajaran berbasis mobile atau M-Learning untuk meningkatkan minat belajar dari siswa yang dimana, pembelajaran dengan model buku yang dianggap sudah kuno dan menurunkan minat belajar siswa. Dengan berkembangnya teknologi, khususnya pada telepon pintar (smartphone), diharapkan dengan menggunakan mobile learning (M-Learning) dapat menjadi tren baru dalam model pembelajaran baru, mendapatkan manfaat, fungsi serta kelebihan dari mobile learning dalam pembelajaran.

Berdasarkan hal tersebut, dapat disimpulkan bahwa perkembangan aplikasi android sebagai sarana media pembelajaran dapat digunakan sebagai media pembelajaran yang bersifat mandiri atau independen, sehingga dapat meningkatkan motivasi belajar siswa dan juga memiliki beberapa kelebihan,diantaranya dapat meningkatkan kemampuan dan motivasi peserta didik dalam belajar dan sebagai media pembelajaran yang interaktif, yang dapat meningkatkan interaksi siswa atau peserta didik dalam belajar.

Kuriulum 2013 terbaru semakin dikuatkan dengan peraturan presiden nomor 87 yaitu tentang penguatan pendidikan karakter dimana dikenal dengan istilah PPK. Dimensi pengolahan karakter tersebut dimaksudkan untuk memperkokoh karakter siswa melalui olah hati (etik), olah rasa (estetis), olah pikir (literasi), dan olahraga (kinestetik) dengan berbagai macam dukungan baik di lingkungan keluarga, sekolah, maupun masyarakat. Gerakan PPK tersebut adalah bagian dari gerakan pemerintah nasional saat ini yang biasa disebut gerakan revolusi mental. 
Ada lima nilai PPK yang diprioritaskan, yaitu; religious, nasionalis, gotong royong, integritas, dan mandiri. Manfaat dari PPK ini yaitu:

- Siswa dapat bersaing di abad 21 ini dengan mampu menjadi kritis, kreatif, komunikatif, dan kolaboratif

- Siswa belajar dengan terintegrasi baik di sekolah maupun di luar sekolah tanpa harus ada pengawasan dari guru

- Revitalisasi sekolah dengan kepala sekolah sebagai manajer dan guru sebagai inspiratory PPK

- Revitalisasi komite sekolah sebagai badan gotong royong sekolah dan ikut serta dalam masyarakat

- Penguatan peran keluarga dengan five days school

- Kolaborasi pemerintah dengan LSM, stakeholder, pegiat kebudayaan, dan sumber-sumber belajar lainya.

Fokus gerakan ppk di kurikulum 2013 edisi revisi ini mencakup tiga hal, yaitu; (1) struktur program, yaitu difokuskan di jenjang sekolah dasar (SD) dan sekolah menengah pertama (SMP) dengan memanfaatkan penguatan kapasitas kepala sekolah, guru, orang tua, komite sekolah, dan pemangku kepentingan lainya, (2) struktur kurikulum, yaitu dengan optimalisasi kurikulum pada satuan pendidikan melalui kegiatain intrakurikuler, kokurikuler, ekstrakurikuler, serta pemanfaatan lingkungan sekitar sekolah, (3) strukutur kegiatan, yaitu membuat sekolah mempunyai ciri khas sehingga bisa mendukung pembentukan karakter empat dimensi yakni olah rasa, olah hati, olah pikir dan olah raga. Gerakan PPK tersebut membuat siswa mempunyai karakter dan kompetensi abad 21 yaitu kritis, kreatif, mampu berkomunikasi dan berkolaborasi.

Untuk basis gerakan PPK sendiri ada 3, yatu; (1) berbasis kelas, yaitu isi kurikulum terintegrasi dalam kelas melalui isi kurikulum dalam mata pelajaran baik tematik maupun terintegrasi, menguatkan manajemen kelas dengan metodologi dan evaluasi pengajaran, dan pengembangan muatan local sesuai dengan kebutuhan daerah, (2) berbasis budaya sekolah, yaitu pembiasaan nilai dari keseharian sekolah, keteladanan orang dewasa di sekolah, adanya ekosistem pendidikan, ruang yang luas untuk siswa didalam kokurikuler dan ekstrakurikuler, memberdayakan manajemen sekolah, mempertimbangkan norma, peraturan, dan tradisi sekolah (3) berbasis masyarakat, yaitu potensi lingkungan sebagai sumber pembelajaran seperti dari tokoh seniman, pegiat budaya, tokoh masyarakat, dunia usaha dan industry, kemudian sineri 
pendidikan dengan lingkup akademisi, pegiat pendidikan maupun LSM, serta sinkronisasi program dan kegiatan melalui kerjasama dengan pemeritah daerah, masyarakat, maupun orang tua.

Dalam implementasinya, ada tiga macam jenis integrasi kurikuler, yaitu intrakurikuler (mempelajari mata pelajaran umum untuk memenuhi kurikulum), kokurikuler (kegiatan yang berkaitan untuk menunjang dan memperdalam kompetensi dasar pada kurikulum), dan ekstrakurikuler (kegiatan untuk mengasah bakat dan minat serta kerohanian). Implementasi gerakan PPK sendiri di kurikulum 2013 edisi revisi ini dilaksanakan secara bertahap dan disesuaikan dengan kondisi dan kebutuhan masingmasing sekolah dan dikembangkan dengan implementasi penuh dan mandiri pada saatnya.

Di dalam membentuk perilaku mandiri, diperlukan beberapa cara dan upaya untuk membangun perilaku mandiri, terutama pada pembentukan karakter siswa. Dengan semakin berkembangnya metode pengajaran dan berkembangnya teknologi saat ini, para pengajar dituntut untuk dapat membangun perilaku independen terhadap para siswa guna untuk meningkatkan kemampuan dari siswa tersebut, bukan secara intelektual saja. Menurut Silvia (2018), dalam membentuk karakter siswa, ada beberapa model pendidikan karakter yang dapat diterapkan, antara lain model pendidikan karakter dengan mata pelajaran, model pembelajaran dengan semua mata pelajaran yang saling terhubung, model pembelajaran secara informal, dan model gabungan. Tetapi dengan model pembelajaran seperti itu, tetap melibatkan warga sekolah, seperti guru dan siswa juga harus saling mendukung pelaksanaan pendidikan karakter yang independen di sekolah.

Menurut Rachael, dkk (2015), untuk membangun karakter yang mandiri atau independen, ada beberapa cara untuk menggambarkan sifat pembelajaran mandiri yang dibagi menjadi 3 kunci karakteristik, yaitu 1.) memahami pendekatan siswa dalam belajar dan menentukan cara yang paling baik untuk memaksimalkan pembelajaran siswa secara efisien, 2.) memotivasi siswa untuk bertanggung jawab atas pembelajaran yang siswa lakukan, dan 3.) kemampuan untuk bekerjasama dengan lainnya guna meningkatkan kemampuan belajar secara menyeluruh. Kemudian, dengan penerapan Self-Determination Theory (SDT), yang melibatkan pembelajaran independen, pengendalian diri secara otonom, dan kondisi psikologis, maka penerapan SDT dapat 
digunakan. Tetapi, masih terdapat tantangan di dalam pengembangan SDT ini. Kondisi atau lingkungan di sekitar juga harus mendukung untuk menumbuhkan lingkungan di mana siswa dapat belajar secara independen dan dapat berkontribusi pada lingkungannya.

Amy (2014) menjelaskan bahwa seseorang yang dapat mengelola konsep belajar untuk memperoleh tujuan dan tidak sepenuhnya bergantung pada seorang guru disebut sebagai independent learner atau orang yang dapat belajar secara mandiri. Untuk memahami konsep tentang pembelajaran independen atau mandiri, yang menjadi perhatian adalah perlakuan pada guru sebagai pengajar di dalam memberikan pengajaran independen kepada siswa, dan perlakuan siswa agar dapat memahami dan belajar secara mandiri dengan perlakuan yang berbeda, untuk siswa dengan usia muda dan siswa dengan usia tua memiliki perlakuan yang berbeda. Setelah itu, baru dilakukan checklist terhadap guru dan siswa agar dapat memahami dan bisa melakukan pembelajaran secara mandiri.

Ciampa (2014) memaparkan tentang pembelajaran independen dengan menggunakan teknologi sebagai sarana belajar. Pada penelitian Ciampa, untuk menemukan informasi mengenai motivasi dari siswa untuk belajar, tantangan di dalam belajar, keingintahuan siswa akan materi pembelajaran yang disampaikan, kontrol belajar, pemahaman siswa terhadap materi, persaingan dan kerjasama antar siswa dapat dilihat melalui penggunaan teknologi mobile yang sering digunakan sekarang ini. Dari data yang ada, telah diambil beberapa siswa di beberapa kelas dengan tingkat kemampuan mulai dari yang jelek hingga yang baik berdasarkan penggunaan teknologi mobile yang siswa punya. Dari hasil penelitian, dengan beberapa pendekatan diatas, dapat disimpulkan dengan menggunakan teknologi mobile seperti android, tablet, I Phone, dapat meningkatkan motivasi siswa dalam belajar dan perlu adanya pengawasan di dalam penggunaan teknologi tersebut.

Berdasarkan hal - hal yang telah disampikan, untuk membangun minat belajar secara mandiri, perlu dilakukan beberapa upaya dan berbagai cara. Guru sebagai pengajar dapat memberikan beberapa cara agar dapat memotivasi siswa untuk belajar secara independen atau mandiri dan juga bisa mengontrol siswa dalam melakukan pembelajaran secara mandiri. Dari segi siswa, juga dituntut untuk lebih aktif dalam kegiatan belajar secara mandiri, dengan caracara yang diberikan oleh guru atau dari motivasi siswa tersebut agar hasil yang 
diperoleh dari pembelajaran secara independen atau mandiri menjadi baik.

Dalam generasi yang penuh dengan perkembangan teknologi dan pencarian informasi yang semakin mudah sekarang, dapat disebut sebagai generasi modern atau generasi milenial. Pada dunia pendidikan, di dalam model pembelajaran dan juga pendekatan terhadap siswa juga memiliki peran penting pada generasi milenial ini.

Menurut Ciampa (2014), penggunaan teknologi mobile seperti smartphone, tablet, laptop sudah merupakan bentuk atau sarana pembelajaran yang baru saat ini. Pengaruh dari penggunaan teknologi mobile terhadap kegiatan yang dilakukan siswa untuk pembelajaran, bisa memberikan dampak positif dan juga dampak negatif, jika tidak ada pengawasan dari pihak-pihak terlibat untuk mengarahkan penggunaan dari smartphone.

Nur (2017) dalam penelitiannya
menjelaskan tentang perkembangan
teknologi dan informasi yang semakin cepat,
yang membuat penyediaan informasi
semakin banyak dan harus memiliki
kecerdasan dalam mengolah informasi.
Dalam penelitian ini, pengetahuan akan
informasi yang telah didapat dari berbagai

macam media menjadi penting di masa milenial ini, terutama di bidang pendidikan. Hal ini terkait dengan banyaknya informasi yang banyak memiliki ketidakpastian secara jelas, dan di dalam dunia pendidikan, dalam penerimaan informasi harus sudah dipastikan sumber dan kejelasan dari informasi yang ada. Sehingga pada generasi milenial ini, perkembangan teknologi sangat berpengaruh terhadap perkembangan di dunia pendidikan.

\section{METODE}

Penelitian ini berkaitan dengan peningkatan kompetensi bahasa Inggris serta perilaku dan perkembangan kurikulum sesuai perubahan zaman. Peneliti menggunakan metode penelitian pendidikan dan pengembangan atau yang lebih dikenal dengan Research \& Development (R\&D) yang mana pengembangan pendidikan tersebut berupa proses, produk, maupun rancangan. Jenis penelitian ini adalah penelitian eksperimen yang bersumber dari penelitian kuantitatif. Rancangan penelitian eksperimen yang akan digunakan adalah rancangan faktorial yang biasa dinamakan dengan factorial design $2 \times 2$. 


\begin{tabular}{|c|c|c|c|c|}
\hline \multicolumn{2}{|c|}{} & \multicolumn{2}{|c|}{ Peningkatan Kompetensi } & \\
\cline { 2 - 5 } & \begin{tabular}{c} 
IBC \\
\multicolumn{2}{|c|}{}
\end{tabular} & $\begin{array}{c}\text { Bhs. Inggris } \\
\mathrm{X}_{1}\end{array}$ & \\
\hline \multirow{2}{*}{$\begin{array}{c}\text { Variabel } \\
\text { Moderator }\end{array}$} & $\begin{array}{c}\text { Berbasis ETG } \\
\mathrm{Y}_{1}\end{array}$ & $\mathrm{X}_{1} \mathrm{Y}_{1}$ & $\mathrm{X}_{2} \mathrm{Y}_{1}$ & $\mathrm{Y} 1$ \\
\cline { 2 - 5 } & $\mathrm{Y}_{2}$ & $\mathrm{X}_{1} \mathrm{Y}_{2}$ & $\mathrm{X}_{2} \mathrm{Y}_{2}$ & $\mathrm{Y} 2$ \\
\hline & & $\mathrm{X} 1$ & $\mathrm{X}_{2}$ & \\
\hline
\end{tabular}

Tabel 2. Variabel Penelitian

Subjek Penelitian ini adalah siswa SMP yang ada di Semarang dan sampel yang diambil adalah dua kelas yang ditentukan secara acak. Masing-masing kelas akan diberikan treatment yang berbeda, yaitu prmbelajaran berbasis ETG dan satunya non ETG. Dalam penelitian ini, ada variabel bebas, variabel terikat, dan variabel moderator. Untuk lebih jelasnya bisa dilihat di tabel dibawah ini:

\begin{tabular}{|l|l|}
\hline Variabel Bebas & $\begin{array}{l}\text { Implementasi PPK Kurikulum } 2013 \text { edisi } \\
\text { revisi }\end{array}$ \\
\hline Variabel Terikat & Kompetensi IBC dan B.Inggris \\
\hline Variabel Moderator & Pembelajaran berbasis ETG dan Non ETG \\
\hline
\end{tabular}

Tabel 3. Variabel Penelitian bag.2 
Peneliti menggunakan tes dan wawancara sebagai instrumen penelitian. Tes tersebut akan digunakan sebagai Pre-Test dan Post-Test. Dalam pengumpulan data, instrumen berupa hasil tes dan wawancara adalah alat untuk mengkoleksi data. Setelah data selesai dikumpulkan, data tersebut diolah menggunakan prosedur data non statistik dan statistik. Prosedur data non statistik berupa kriteria pencapaian peningkatan dan prosedur data statistik meliputi menghitung mean, median, mode, frequency distribution, standar deviation, multifactor anova, two way anova, t-test, \& effectiveness test. Dalam penelitian ini, ketua peneliti bertanggung jawab atas penelitian, analisis data, pembuatan laporan dan luaran. Anggota peneliti membantu proses pengumpulan data dan menyiapkan bahan ajar berbasis ETG, dll.

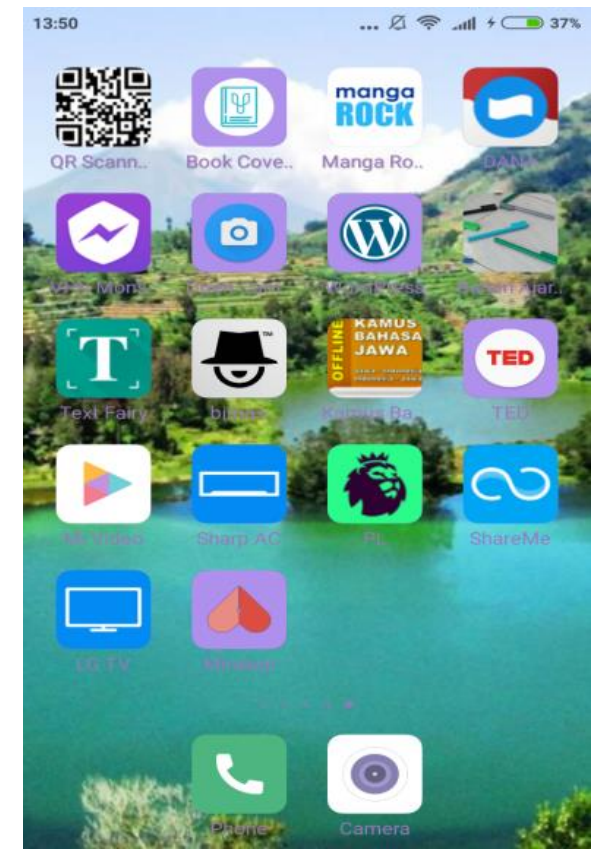



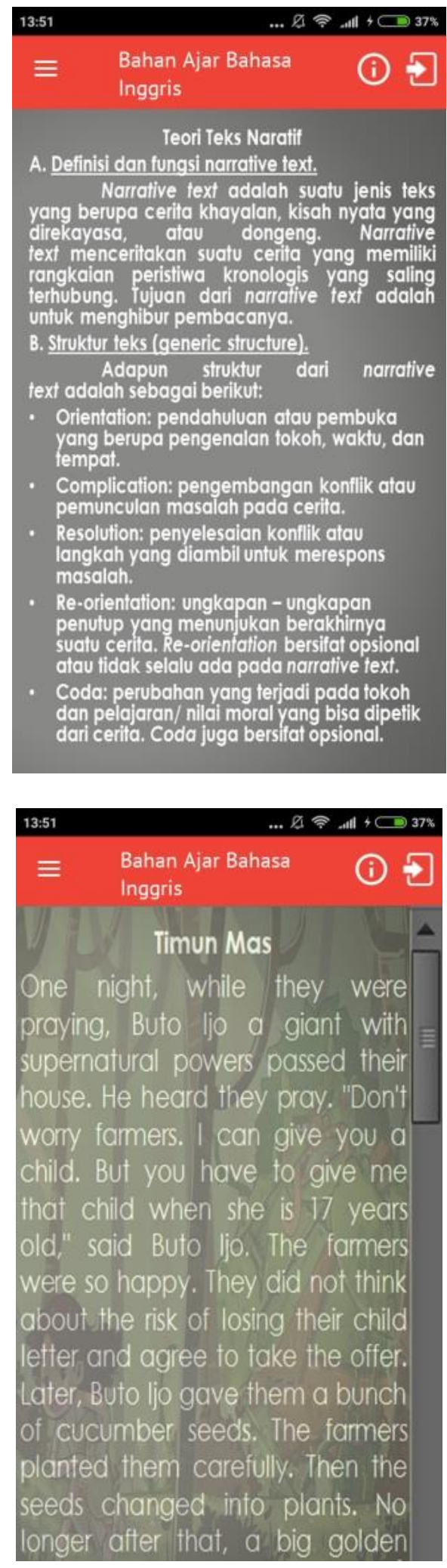


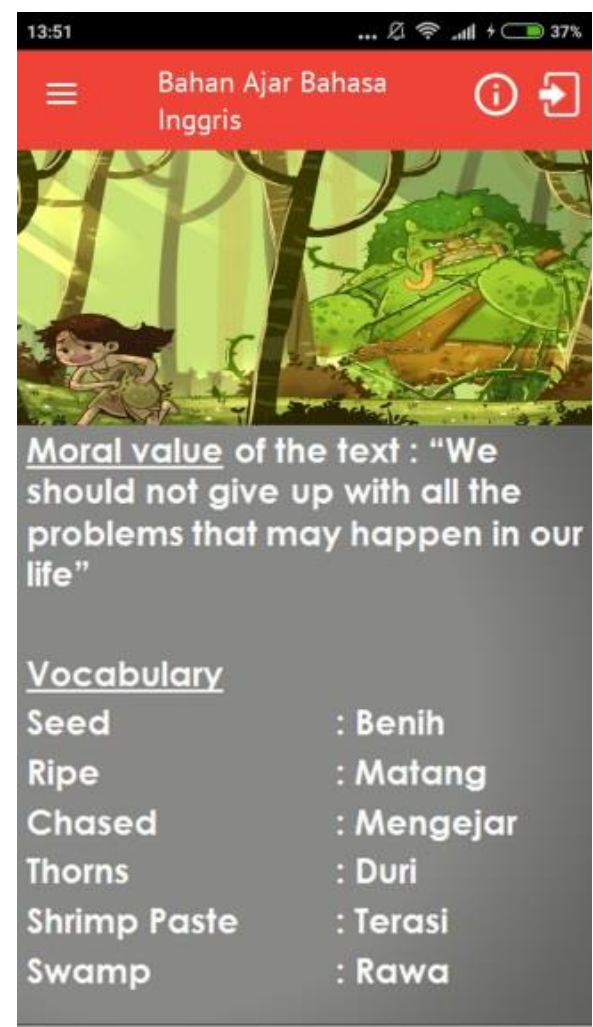

Gambar 1. Desain Aplikasi Pembelajaran Teks B. Inggris Berbasis Sistem Operasi Android 


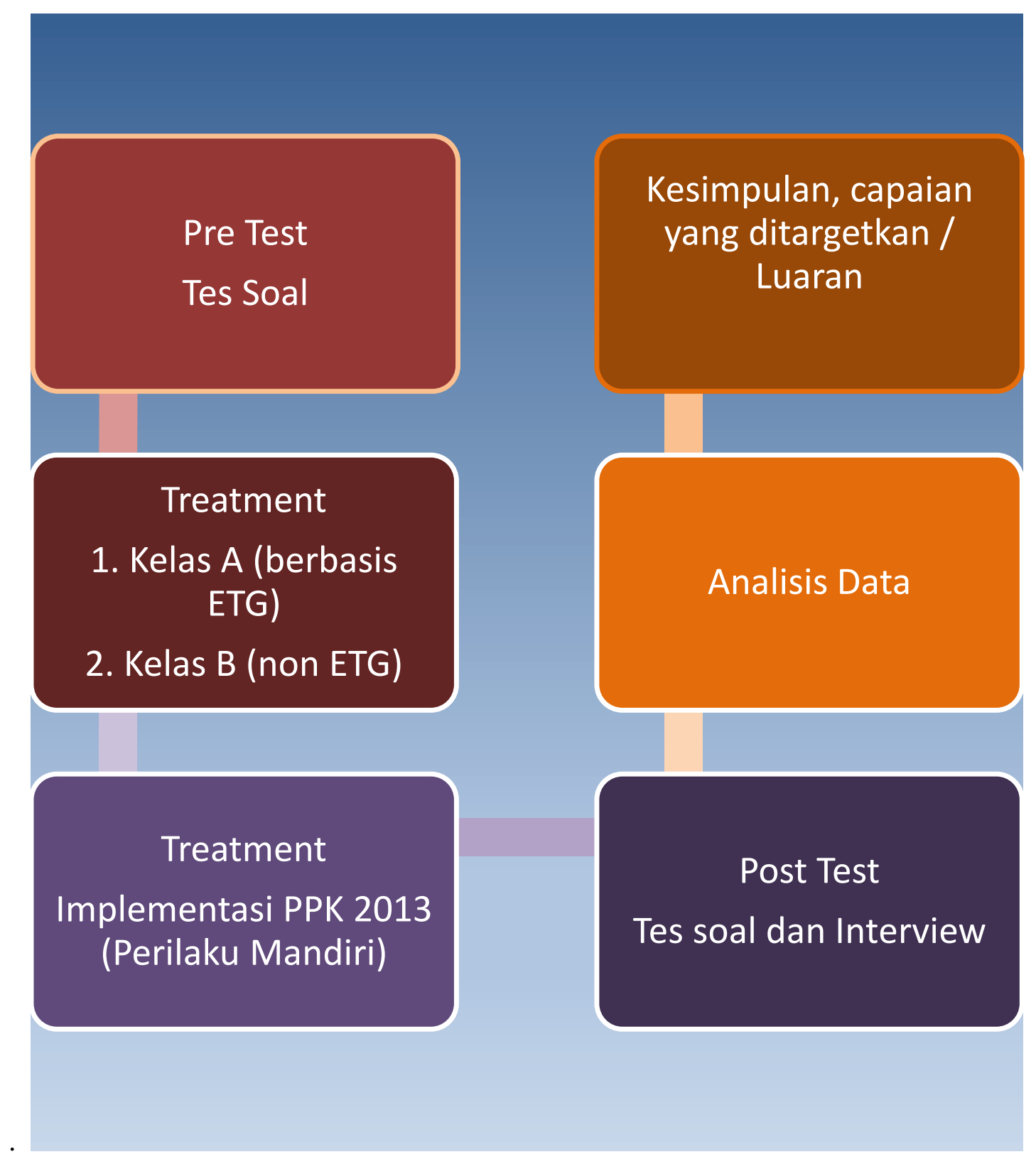

Gambar 2. Alur Penelitian

\section{HASIL DAN PEMBAHASAN}

Tujuan Penelitian ini adalah untuk peningkatan kemampuan IBC dan Bahasa Inggris pada siswa SMP dengan berbasis ETG dan membuat komparasi antara peningkatan tersebut dengan yang Non-ETG. Peneliti melakukan treatment dengan membagi kelas menjadi dua grup, yaitu kelas kontrol dan kelas eksperimen. Kelas eksperimen adalah peningkatan IBC dan 
Bahasa inggris berbasis ETG, sedangkan kelas kontrol dengan berbasis Non-ETG. Kemudian, peneliti melakukan pre-test untuk kelompok-kelompok tersebut dan diikuti dengan treatment. Fase yang terakhir adalah pemberian post-test. Setelah peneliti mendapatkan semua data, peneliti mengkalkulasi data menggunakan normality test dan homogenity test. Karena semua data normal dan homoggen, instrumen yang digunakan sesuai untuk diberikan kepada siswa.

Kemudian peneliti menulis deskripsi data terlebih dahulu sebelum hasil akhir penelitian dijabarkan. Pertama, skor kelas eksperimen dalam pre-test adalah 880 untuk nilai rata-rata, mean 25.14; median 25 , mode 10 , standard deviation 13.63 , skor minimum 5.0; dan skor maksimum adalah 50. Semua murid nilainya sangat kurang pada saat itu. Tapi, pada saat post-test, skor meningkat menjadi 2530, mean 72.29; median 70, mode 60 , standar deviasi 11.53 , skor minimum 55; dan skor maksimum 95 dengan kategori nilai kurang $22.86 \%$, cukup $28.57 \%$, baik $20 \%$, sangat baik $20 \%$ dan excellent $2.86 \%$. Kedua, Mengenai kontrol grup. Nilai pres-test adalah 910, mean 26.00; median 20, mode 15 , standar deviasi 15.18, nilai minimum 5.0; dan nilai maksimum 55 dengan kategori nilai sangat kurang berjumlah $97.14 \%$ dan kurang $2.86 \%$. dan untuk post-test sendiri nilai total 2070, mean 59.28; median 60, mode 70 , standar deviasi 7.19, skor minimum 45dan skor maksimum adalah 75 dengan kategori sangat kurang $17.14 \%$, kurang $60.0 \%$, cukup $14.29 \%$, dan baik $8.57 \%$. Ketiga, deskripsi tentang peningkatan kemampuan Bahasa Inggris dan IBC kaitan dengan berbasis ETG dan Non-ETG. Peningkatan IBC pada 25 siswa dengan berbasis ETG adalah (71.4\%) dan10 siswa berbasis Non-ETG (28.6\%); Kaitan dengan peningkatan Bahasa Inggris berjumlah 17 siswa (48.6\%) dan 18 siswa berbasis Non-ETG (51.4\%).

Dari uraian tersebut, peneliti menghitung temuan untuk menjawab masalah. Peningkatan IBC dengan berbasis ETG: Cohen's d adalah 4.09074 dan ukuran efek adalah 0,89837. Peningkatan IBC dengan berbasis Non-ETG: Cohen's d adalah 3,81156 dan ukuran efek 0,88550. Peningkatan Bahasa Inggris berbasis ETG menghasilkan: Cohen d adalah 3,90581 dan ukuran efek 0,89009. Peningkatan Bahasa Inggris Berbasis Non-ETG: Cohen's d adalah 4,68711 dan ukuran efek 0,91976. Perbandingan peningkatan kemampuan IBC dan Bahasa Inggris seperti dibawah ini: 


\begin{tabular}{|l|l|l|l|l|}
\hline Informasi & \multicolumn{2}{|l|}{ IBC } & \multicolumn{2}{l|}{ Bahasa Inggris } \\
\hline ETG & ETG & Non-ETG & ETG & Non-ETG \\
\hline Rata-rata pre-test & 28.6 & 16.5 & 26.0 & 15.5 \\
\hline Standar Deviasi & 12.206 & 13.753 & 11.726 & 12.122 \\
\hline Rata-rata post-test & 75 & 65.5 & 68.8 & 60.0 \\
\hline Standar Deviasi & 10.408 & 11.8907 & 10.132 & 5.7753 \\
\hline Cohen's D & 4.09074 & 3.81156 & 3.90581 & 4.68711 \\
\hline Ukuran Efek & 0.89837 & 0.88550 & 0.89009 & 0.91976 \\
\hline Kategori & Besar & Besar & Besar & Besar \\
\hline
\end{tabular}

Tabel 4. Hasil Analisis Data

Dari tabel diatas, peneliti mengetahui bahwa peningkatan IBC dengan berbasis ETG lebih tinggi nilainya daripada kemampuan Bahasa Inggris yang berbasis Non-ETG. Kemudian perhitungan tersebut dihitung menggunakan tes Levene dengan nilai probabilitas $0.558>0.05$, maka semua varians sampel adalah sama (homogen) dan ANOVA memiliki nilai signifikan 0,937> 0,05 yang berarti tidak signifikan. Hubungan antara peningkatan Bahasa Inggris dengan ETG dihitung dengan tes Levene yang mempunyai nilai probabilitas $0.000>0.05$, maka semua varian sampel tidak sama and ANOVA mempunyai nilia signifikansi 0.478 $>0.05$ yang mana tidak signifikan.

Berdasarkan temuan, yang pertama adalah menganalisis peningkatan IBC dengan berbasis ETG. Berdasarkan rata-rata skor post-test dan pre-test, efisiensi dapat dihitung dengan kalkulator Cohen. Hasil Cohen d adalah 0,89 , yang dianggap sebagai ukuran efek yang relatif besar. (0,8 + Efek besar). Berdasarkan perhitungan, ETG dalam peningkatan IBC kepada siswa kelas delapan efektif karena terjadi peningkatan.

Yang kedua adalah untuk menganalisis peningkatan IBC dengan berbasis Non-ETG, efisiensi dapat dihitung dengan kalkulator Cohen. Hasil Cohen d adalah 0,88 , yang dianggap sebagai ukuran efek yang relatif besar. Berdasarkan perhitungan, terjadi peningkatan IBC kepada siswa kelas delapan efektif meskipun berbasis Non-ETG.

Yang ketiga adalah menganalisis Peningkatan Bahasa Inggris berbasis ETG. Berdasarkan rata-rata post-test dan pre-test, efisiensi dapat dihitung dengan kalkulator Cohen. Hasil Cohen d adalah 0,89, yang dianggap sebagai ukuran efek besar. 
Berdasarkan perhitungan ini, terjadi peningkatan yang efektif.

Yang keempat untuk menganalisis Peningkatan Bahasa Inggris berbasis NonETG. Berdasarkan rata-rata post-test dan pretest, efisiensi dapat dihitung dengan kalkulator Cohen. Hasil Cohen d adalah 0,91, yang dianggap sebagai ukuran efek besar. Berdasarkan perhitungan ini, terjadi peningkatan yang efektif.

Analisis kelima adalah membandingkan mana yang efektif antara peningkatan IBC dan kemampuan bahasa inggris untuk basis ETG maupun Non-ETG. Perhitungannya adalah peningkatan IBC memiliki kategori besar yang diterapkan pada siswa dengan berbasis ETG $(0,89837)$ dan siswa dengan Non-ETG $(0,8855)$. Sementara itu, peningkatan kemampuan Bahasa Inggris memiliki kategori besar juga yang diterapkan pada siswa dengan berbasis ETG $(0,89009)$ dan siswa dengan Non-ETG $(0,91976)$. Hasil penelitian ini membuktikan bahwa peningkatan IBC lebih efektif daripada kemampuan Bahasa Inggris dalam proses pembelajaran siswa dengan berbasis ETG. Tapi, peningkatan kemampuan Bahasa Inggris lebih efektif menggunakan NonETG.

Keenam adalah menganalisis peningkatan IBC dengan ETG maupun Non-
ETG. Berdasarkan output, menunjukkan bahwa nilai signifikan adalah 0,937 yang berarti tidak signifikan $(0,937>0,05)$. Ini berarti tidak ada ihubungan antara tes dengan ETG dalam mempengaruhi peningkatan IBC. Dengan kata lain, ETG tidak mempengaruhi siswa dalam mempengaruhi peningkatan IBC. Dari perhitungan itu, peneliti menemukan bahwa tidak ada interaksi antara peningkatan IBC dengan ETG dalam mengajar siswa.

Yang ketujuh adalah menganalisis interaksi antara peningkatan Bahasa Inggris dengan ETG maupun Non-ETG. Berdasarkan output, menunjukkan bahwa nilai signifikan adalah 0,403 yang berarti tidak signifikan $(0,403>0,05)$. Ini berarti tidak ada interaksi antara tes dengan motivasi dalam mempengaruhi skor rata-rata peningkatan kemampuan Bahasa Inggris. Dengan kata lain, ETG tidak mempengaruhi siswa dalam mempengaruhi peningkatan Bahasa Inggris. Dari perhitungan itu, peneliti menemukan bahwa tidak ada interaksi antara peningkatan Bahasa Inggris dan ETG dalam mengajar.

\section{KESIMPULAN}

Hasil temuan menunjukkan bahwa peningkatan IBC dalam PPK kurikulum 2013 
lebih efektif dalam proses pembelajaran dengan ETG dan Non-ETG. Juga, peningkatan kemampuan Bahasa Inggris efektif dalam pengajaran dengan berbasis ETG dan Non-ETG tetapi skor pre-test dan post-test lebih rendah daripada skor dalam peningkatan IBC. Sebagai perbandingan, peningkatan IBC lebih efektif untuk siswa dengan berbasis ETG daripada kemampuan Bahasa Inggris itu sendiri dan sebaliknya, kemampuan berbahasa Inggris lebih sesuai dengan berbasis Non-ETG daripada peningkatan IBC yang menunjukkan sebaliknya. Selanjutnya, tidak ada interaksi antara Peningkatan IBC dengan ETG maupun Non-ETG. Dan, tidak ada interaksi apa pun antara peningkatan Bahasa Inggris dan ETG. Kesimpulan dari hasil: terjadi peningkatan dalam IBC, tetapi tidak ada pengaruh terhadap penggunaan introdusir Bahas Ajar ETG maupun Non-ETG dalam implementasi PPK Kurikulum 2013.

\section{DAFTAR PUSTAKA}

Ambarwati, Noviani Kurnia., Wiryasaputra, Rita., dan Puspasari, Shinta. 2016. Pembangunan Modul $\begin{array}{llr}\text { Pembelajaran } & \text { Bahasa } & \text { Inggris } \\ \text { Menggunakan } & \text { GMT } & \text { Berbasis }\end{array}$
Android, ULTIMATICS, Vol. VIII,

No.2, ISSN 2085-4552:

Amy, C.Zaring. 2014. Building Independence by Teaching Students to Self-Monitor. IDEAS Conference Epworth by the Sea, June 2014 Anofrizen., dan Fadlan, Alfi. 2015. Mobile Application Pembelajaran Interaktif Bahasa Inggris Berbasis Android Menggunakan Metode Rapid Application Development (RAD) (Studi Kasus : LBPP LIA Pekanbaru), Jurnal Rekayasa dan Manajemen Sistem Informasi, Vol. 1, No. 2, Agustus 2015, pp. 23-30, ISSN 2460-8181

Azwar, Rahmat, dkk. 2018. Aplikasi MLearning Mata Pelajaran Bahasa Indonesia Menggunakan Android Studio, Program Studi Manajemen Informatika Politeknik Muara Teweh, Technologia, Vol.9, No.1 JanuariMaret 2018

Ciampa. 2014. Learning in a Mobile Age: An investigation of Student Motivation, Journal of Computer Assisted Learning, Canada, doi: 10.1111/jcal. 12036

Dirgeyasa, Wy. 2016. Genre-Based Approach: What and How to Teach and to Learn Writing, English 
Language Teaching (ELT), Vol.9, No.9, ISSN 1916-4742 E-ISSN 19164750: Canadian Center of Science and Education Publisher, viewed 14 April 2018

$<$ https://files.eric.ed.gov/fulltext/EJ1 107874.pdf>

Harahap, Nazzrudin Safaat., dan Putri, Fatima Akmal. 2017. Rancang Bangun Aplikasi Pembelajaran Bahasa Inggris Pada Platform Android, CoreIT, Vol.3, No.1, ISSN 2460-738X

Hidayatun, Nunung, dkk. 2018. Animasi Interaktif Berbasis Android untuk Mengenal Huruf Hiragana Katakana, Journal Speed - Sentra Penelitian Engineering dan Edukasi, Vol.10 No.1 2018, ISSN : 1979-9330 (Print) - 2088-0154 (Online)

Lutfiansyah. 2016. Penggunaan Aplikasi Mobile Pembelajaran Bahasa Inggris Android pada Pembelajaran Bahasa Inggris (Pengamatan Terhadap Sumber

Belajar Berbasis Android Melalui Media Mobile Smartphone), Eduscience, Vol.2, No.1

Musahrain, dkk. 2017. Pengaplikasian Mobile Learning Sebagai Media dalam Pembelajaran, Prosiding
Seminar pendidikan Nasional, Pascasarjana Teknologi Pendidikan FKIP Universitas Sebelas Maret, 26 Maret 2017

Nur Ainiyah. 2017. Membangun Penguatan Budaya Literasi Media dan Informasi Dalam Dunia Pendidikan, JPII, Vol.2, No.1, Prasetyo, Yogo D, dkk. 2015. Pengaruh Media Pembelajaran Kimia Berbasis Android Terhadap Peningkatan Motivasi Belajar Siswa, Seminar Nasional Penelitian dan Kajian Konseptual Mengenai Pembelajaran Sains Berbasis Kemandirian Bangsa, Magister Pendidikan Sains dan Doktor Pendidikan IPA FKIP UNS, ISSN: 2407-4659

Yula, Silvia. 2018. Peranan Konselor Dalam Penguatan Pendidikan Karakter. Prosiding Seminar Nasional Pendidikan, STKIP ANdi MAtappa Pangkep

https://cerdasberkarakter.kemdikbud.go.id https://www.kemdikbud.go.id/main/files/do wnload/7bdf2592741007e

http://setkab.go.id/wpcontent/uploads/2017/09/Perpres_No mor_87_Tahun_2017.pdf 
https://www.gadoe.org/Curriculum-

Instruction-and-Assessment/Special-

Education-

Services/Documents/IDEAS\%20201

4\%20Handouts/Build\%20Independ

$\%$ 20by\%20Tching\%20Stud\%20to\%

20Self-Monitor.pdf

https://www.heacademy.ac.uk/system/files/r

esources/independent_learning.pdfds

$\mathrm{t}$ 